\title{
Geçmişten Günümüze Almanca Öğretmenliği Lisans Programlarına İlişkin Karşılaştırmalı Bir Çalışma
}

\author{
Aysel Deregözü (iD), İstanbul \\ doi) https://dx.doi.org/10.37583/diyalog. 802258
}

$\ddot{o}_{z}$

Bu çalışmada amaç, geçmişten günümüze kadar Almanca öğretmenliği için hazırlanan lisans eğitimi programlarının oluşturulma gerekçelerinin incelenmesi ve güncel gerekliliklerin programlara yansıma biçimlerinin ortaya konulmasıdır. Bu amaç kapsamında, geçmişten günümüze kadar kullanılan Almanca öğretmenliği lisans programlarında alan ve alan öğretimi dersleri incelenmektedir. Elde edilen bulgulara bağlı olarak uygulayıcılara ve program geliştiricilere öneriler sunulmuştur. Bu kapsamda, Almanca öğretmenliği alan ve alan öğretimi dersleri doküman analizi yöntemiyle incelenmiştir. Almanca öğretmenliği programını diğer branşlardan ayıranın alan ve alan öğretimi dersleri olduğundan dolayı, incelemeye bu dersler esas alınmıştır. Çalışmada, 1998-1999, 2006-2007 ve 2018 -2019 y1lları Almanca öğretmenliği lisans programları incelenmiştir. İçerik analizi yöntemiyle alan ve alan öğretimi dersleri konularına göre kategorilere ayrılmış, genel program içerisinde dağılımları, teorik ve uygulama ders saatleri ve kredi sayısı incelenmiştir. Derslerin alan ve alan öğretimi başlıklarına ayrılmasında, ders içerikleri göz önünde bulundurulmuştur. Sınıflamada, Temel Dil Becerileri, Dilbilgisi, Çeviri Bilim, Dilbilim, Edebiyat Bilim, Ülke Bilgisi, Kültür Bilim ve Yabancı Dil Öğretimi ölçüt olarak alınmıştır. Elde edilen bulgular tablolar halinde sunulmaktadır. Elde edilen bulgular göstermektedir ki, y1llara bağl1 olarak alan öğretimi derslerinin sayısında bir düşüş, pedagojik derslerin sayısında bir artış olmuştur. Bununla birlikte uygulama ders saati alan derslerinde sıfira inmiştir. Temel Dil Becerileri ve Edebiyat Bilimi altında yer alan derslerin ders saatlerinde bir düşüşün olduğu görülmektedir. Alan ve alan öğretimi dersleri arasında temel dil becerilerinin öğretimine yönelik olan derslerin ders sayı ve saatlerinin arttırılması ve dil öğretiminde esas olan uygulama becerisinin gelişimi olduğu için uygulama saatlerinin eklenmesi önerilmektedir. 2018-2019 eğitim programının bu konularda geliştirilmesi gerektiği de anlaşılmaktadır.

Anahtar Sözcükler: Öğretmen ĕgitimi, Almanca öğretmen eğitimi, müfredat, bilgi, beceri.

\section{Abstract \\ An Evaluation of the Curricula for German Language Teacher Education Programs}

The purpose of this study is to examine the aims of preparing and revising curricula for the German Language Teacher Education Programs in Turkey and to investigate how current needs are implemented in these programs. For this aim, the curricula are examined in view of subject content knowledge and didactic knowledge, as these are domain - specific knowledge areas for the language teaching profession. Out of the findings, suggestions for practitioners are made. With this aim, the subjects related to the subject content knowledge and the didactic knowledge are examined with content analysis method. In the study, the curricula developed in the years of 1998 - 1999, $2006-2007$ and $2018-2019$ are examined. 
With content analysis the subjects related to subject content knowledge and didactic knowledge are analyzed and categorized. The subjects are categorized under the headings basic language skills, grammar, translation, linguistics, literature, regional history, cultural studies and language teaching. Furthermore, subjects related to subject content knowledge and didactic knowledge are examined in view of the distribution related to the other subjects and the whole program, lesson hours, theoretical and practical part and credit points. The findings revealed that within years there is a decrease in the amount of subjects related to basic language skills and literature, but an increase of pedagogical subjects. Furthermore, subjects in the field of subject content knowledge and didactic knowledge consist of just theory, but not practice. As in language teaching, it is essential to have practical skills in the field of language teaching, it is recommended to increase practice and decrease theory. Furthermore, an increase in favour of subjects related to didactic knowledge is recommended.

Keywords: Language teacher education, German language teacher education, curriculum, knowledge, skill. 


\section{EXTENDED ABSTRACT}

The aim of this study is to evaluate the curricula for German Language Teaching programs prepared by the Turkish Higher Education Council and to examine how requirements of their time are implemented in the education programs and to investigate the change of the curricula over the past years. For this aim, the curricula developed and implemented in the years of 1998-1999, 2006-2007 and 2018-2019 are evaluated in view of revision/ development reasons and the distribution of domain-specific subjects.

For the determination of domain - specific subjects, subjects covering subject content knowledge and didactic knowledge are specified. In the study, qualitative research method is used. With content analysis, the subject contents are examined and categorized under the aspects basic language skills, grammar, translation, linguistics, literature, regional history, cultural studies and language teaching. Furthermore, domain-specific subjects are examined according to the distribution within the whole curriculum, lesson hours, credit points and the implementation of theory and practice.

The findings related to the reasons of developing and implementing a new curriculum showed that the main objective in developing the curriculum in the years of 1998-1999 was that teacher candidates were not appropriate qualified for the profession and that subjects in the field of language teaching were not sufficient. Whereas the curriculum of the years 2006-2007 were mainly developed for the adaptation to the European higher education area due to the Bologna Process, the curriculum in the years of 2018-2019 was mainly developed to respond to the needs of the Turkish education area. Furthermore, one main objective was that the Turkish Ministry of Education published a competency framework for teachers. Hence, teacher education had to prepare teacher candidates for the profession in accordance with the new requirements.

The findings revealed that within years the amount of domain - specific subjects decreased, but subjects related to pedagogical content knowledge increased. Furthermore, lesson hours of domain-specific subjects show a decrease compared to pedagogical content knowledge subjects. When examining subjects in view of the aspects basic language skills, grammar, translation, linguistics, literature, regional history, cultural studies and language teaching, then it is evident that subjects in the field of basic language skills and literature show a decrease over the past years. Whereas in the curriculum 1998-1999 the total lesson hours of subjects in the field of basic language skills cover 24 hours, in the curriculum of the years 2018-2019 the lesson hour cover just 14 hours in the whole program. Subjects in the field of literature cover 18 hours in the curriculum of the years 1998-1999, but in the curriculum 20182019 just 10 hours. Even though these subjects show a decline in the whole new program, subjects related to language teaching show a slight increase of lesson hours. In the curriculum of the years 1998-1999 subjects related to language teaching cover 20 lesson hours, in 2018-2019 22 hours. That means that in general domain-specific subjects and their lesson hours have declined within years. Moreover, even though language teaching means to have practical knowledge besides theoretical knowledge, in the new curriculum, there is no practical part implemented. The domain-specific subjects consist just of theory. Hence, it is recommended to revise the current 
curriculum in view of these findings. Which means that especially the amount of subjects related to basic language skills and language teaching have to be increased. Furthermore, subjects in these fields should also cover practical parts as they consist in this form just of theory.

As the revision reasons for the current curriculum is to update the old one as it seems not to meet the current requirements and expectations of the Turkish education system, the revision needs to be revised accordingly the findings. That means, to ensure the quality of education, teacher education and the programs have to be revised according to the current needs. Hence, an overall revision of the curriculum with respect of domain-specific subjects is recommended. 


\section{Giriş}

Eğitimin etkili olmasında iyi hazırlanmış eğitim programları önemli bir rol oynamaktadır (Kocayiğit/ Aykaç 2019: 257). Nitekim, eğitim programları doğrultusunda öğrenme ortamları hazırlanmakta ve eğitim faaliyetleri yürütülmektedir. "Öğrenene, okulda ve okul dışında planlanmış etkinlikler yoluyla sağlanan öğrenme yaşantıları düzeneğii” (Demirel 2012: 6) ve "Kişide gözlenmesi kararlaştırılan hedefleri, bunları gerçekleştirebilecek düzenli eğitim ve sınama durumlarını içeren dirik bir örüntü” (Sönmez 2009; akt. Budak, 2009: 66) olarak tanımlanan eğitim programları ile eğitimin planlı ve sistemli yürütülmesi sağlanmaktadır. Herşeyden öte eğitim programları, “(...) bireylere kazandırılacak davranış, standartlarını, öğretilecek bilgi, beceri ve tutumları, öğretme-öğrenme etkinliklerini ve değerlendirme süreçlerini belirler" (Gültekin 2013: 128). Bu açıdan bakıldığında, eğitim programları öğretilecek içeriği göstermekte ve eğitimi şekillendirmektedir. Ancak değişen koşullar, eğitim programlarının da yenilenmesini ve yeni koşullara uygun hale getirilmesini zorunlu k1lmaktadir.

Öğretmen adaylarının yetiştirilmesi amacıyla da eğitim programları oluşturulmakta ve zamansal değişimlere bağlı olarak gözden geçirilmekte ve yenilenmektedir. Ülkemizde, 1982 yılında Eğitim Fakültelerinin kurulması ile birlikte, ilk öğretmen eğitimi lisans programı da uygulamaya konulmuştur. $\mathrm{Bu}$ tarihten itibaren eğitim programları çeşitli dönemlerde gözden geçirilmiş ve yenilenmiştir. Bu çalışmalar neticesinde Eğitim Fakültelerinde, 1998-1999, 2006-2007 ve 2018-2019 eğitim öğretim yılı itibariyle uygulamaya konulan öğretmen eğitimi lisans programları oluşturulmuştur. Bu kapsamda, Almanca öğretmenliği lisans programları da yenilenmiş ve Türkiye'de tüm Almanca öğretmenliği programlarında kullanılması zorunlu olmuştur. Ancak, 2018-2019 öğretmen eğitimi lisans programlarının geliştirilmesinin üstünden henüz iki yıl geçmişken, YÖK 18.08.2020'de bir karar alarak, eğitim fakültelerine yetki devrinde bulunduğunu açıklamıştır. Karara göre, bundan böyle Eğitim/ Eğitim Bilimleri Fakültelerinin öğretmenlik lisans programlarının geliştirilip güncellenmesi çalışmaları, Türkiye Yeterlikler Çerçevesi ve Milli Eğitim Bakanlığı tarafından belirlenen Öğretmenlik Mesleği Yeterlikleri dikkate alınarak ilgili yükseköğretim kurumları tarafından yapılacaktır. Kararın alınma gerekçeleri arasında, eğitimde program geliştirmenin dinamik ve süreklilik arz eden bir süreç olması ve üniversitelerin de bu dinamik süreci yönetebilecek düzeyde kapasiteye ve öğretim elemanlarının da program geliştirme ve güncelleme konusunda yetkinliğe sahip olması gösterilmektedir (YÖK, 2020). YÖK, bu düşüncelerden yola çıkarak, konuyu 10.08.2020 tarihli Yükseköğretim Genel Kurul toplantısında müzakere ederek, öğretmenlik programlarına ilişkin 12.04.2018 tarihli Yükseköğretim Genel Kurul kararını iptal etmiştir. Bundan böyle, öğretmenlik programlarındaki derslerin, müfredatın ve kredilerin belirlenmesinde, yükseköğretim kurumlarının ilgili kurullarının yetkilendirilmesi kararına varılmıştır. Ancak, müfredat belirlemede iki koşulun yerine getirilmesi zorunlu tutulmaktadır. Birinci koşul, ders kategorilerinin oluşturulmasında alan eğitimi, öğretmenlik meslek bilgisi ve genel kültür dersleri şeklindeki gruplandırmanın esas alınması, ikinci koşul ise ders sayısı, ders saati/ kredi sayısı ve yoğunluğu konusunda yine bu gruplandırmadaki sıralamaya dikkat edilmesidir (YÖK, 2020). 
YÖK tarafindan alınan bu kararın, öğretmen eğitimi lisans programları ile ilgili tarihi bir karar olarak nitelendirilmesi ise, bugüne kadar YÖK öncülüğ̈̈nde merkezi bir şekilde oluşturulan müfredat geliştirme çalışmalarından vazgeçilmesi ve yükseköğretim kurumlarına müfredat oluşturma yetkisini devretmesi ile ilgili olduğu da anlaşılmaktadır. Henüz yeni bir düzenleme olduğundan, bu kararın eğitim programlarına nasıl yansıyacağı ve bugüne kadar ortak zorunlu bir eğitim programı ile öğretmen yetiştiren kurumlarda mezun olan öğretmen adaylarının eğitimlerine ve mesleki yetkinlik gelişimlerine ne şekilde yansıyacağı ise, yeni eğitim programlarının geliştirilmesi ve uygulanması ile birlikte ortaya çıkacaktır.

YÖK (2020), bu kararın üniversitelere çok geniş bir hareket serbestisi tanıyacağını belirtmekte, ancak Türk Milli Eğitimine öğretmen yetiştiren kurumların uygulamada birliği nasıl sağlayacakları konusunda bir bilgiye yer vermemektedir. YÖK (2020) bu konuda sadece 2018 yılında yapılan düzenlemeye değinerek, alan eğitimi derslerinin \%45-50, öğretmenlik meslek bilgisi derslerinin \%30-35 ve genel kültür derslerinin \%15-20 oranlarında eğitim programlarında yer aldığına dikkat çekmekte, ancak yeni düzenlemeye göre belli bir orandan söz etmemektedir. Buna karşllı, müfredat oluşturulurken, alan eğitimi, öğretmenlik meslek bilgisi ve genel kültür ders gruplandırmasının göz önünde bulundurulması gerektiğine vurgu yapılmakta, bu derslere eğitim programlarında hangi ağırlıklarda yer verilmesi gerektiğine ise değinilmemektedir. Öğretmen eğitiminde ise, bir standardın bulunması zorunlu görülmektedir (bkz. Türk Eğitim Derneği, 2009). Yeni düzenlemede ise standart, mesleki yeterlilikler esas alınarak oluşturulmaya çalışılmaktadır. Bu yaklaşım, meslek için gerekli bilgi ve becerilerin gelişmesine olanak tanıması açısından olumlu olarak nitelendirilebilir.

Alan yazında, öğretmenlikte mesleki yetkinliği sağlayan belli bir takım derslerin olduğu ve bunların eğitim programlarında yer alması gerektiği üzerinde durulmaktadır (Königs 2009: 27). Bu dersler incelendiğinde ise, üç ana başlık altında ele alındığı görülmektedir. Bunlar; pedagojik bilgi, alan bilgisi, alan öğretimi bilgisidir. Pedagojik bilgi, her öğretmen için gerekli olan öğretmenlik temel bilgisini, alan ve alan öğretimi bilgisi ise, alana özgü bilgi ve becerileri kapsamaktadır. Bu bilgi ve becerilerin öğretmenlerde mesleki yetkinliği sağladığı vurgulanmaktadır (Baumert/ Kunter 2006: 482). Ancak alan bilgisi ile ilgili derslerin edebiyat ve dilbilim gibi temel bilgileri içeren dersler olduğu ve bu bilginin eğitim ve öğretimin kalitesinde belirleyici olmadığı da ifade edilmektedir (König vd. 2016: 326-327). Buna karşıllk, öğretme ve öğrenme ile ilgili bilgileri içeren alan öğretimi bilgisi derslerinden elde edilen bilgiler doğrudan eğitim ve öğretimde kullanılmakta ve eğitimin niteliğini belirlemektedir (bkz. Deregözü 2020: 39). Nitekim, öğretmenlikte bir branşı diğer bir branştan ayıran bilginin, alan ve alan öğretimi bilgisi olduğu vurgulanmaktadır (Baumert/ Kunter 2006: 482). Bu bilgi ise, öğretmen eğitimi sürecinde kazanılmakta ve mesleki yetkinlikte belirleyici olmaktadır. König vd. (2016: 326-327) vurguladığı gibi, alan öğretimi bilgisi ile ilgili dersler dil öğretiminin niteliğini belirlemekte ve eğitim programlarında ağırlıklı yer alması gereken dersler arasında bulunmaktadır. Bundan dolayı, Almanca öğretmenlerinin yetiştirilmesi amacıyla oluşturulan eğitim programlarında da alan öğretimi bilgisi içeren derslere ağırlıklı olarak yer verilmesi son derece önem arz etmektedir.

$\mathrm{Bu}$ noktada akla gelen soru, bugüne kadar oluşturulmuş olan Almanca 
öğretmenliği lisans eğitimi programlarının bu derslere ne ölçüde yer verdiğidir. Almanca öğretmenliği lisans programının alan eğitimi ile ilgili derslerinin incelenmesi, bu sorunun cevaplanmasında yardımcı olacaktır. Bununla birlikte, Almanca öğretmenliği lisans eğitimi programlarında alan eğitimi derslerinin zaman içerisinde genel program içerisinde dağılımının tespit edilmesi, yeni düzenlemeye göre yetkilendirilen yükseköğretim kurullarının kendi eğitim programlarını oluşturmalarında yardımcı olması açısından önemlidir.

\section{Amaç}

$\mathrm{Bu}$ kapsamda çalışmanın amacı, geçmişten günümüze Almanca öğretmenliği lisans programlarının oluşturulma ve yenilenme gerekçelerinin belirlenmesi ve alan eğitimi derslerinin dağılımlarının zaman içerisinde değişimlerinin incelenmesidir.

Bu kapsamda, aşağıdaki araştırma sorularına cevap aranmaktadır:

1. 1998-1999, 2006-2007 ve 2018-2019 y1llarında uygulamaya konulan Almanca öğretmenliği lisans programlarının oluşturulma gerekçeleri nelerdir?

2. 1998-1999, 2006-2007 ve 2018-2019 Almanca öğretmenliği lisans programlarında alan ve alan öğretimi bilgisi ile ilgili derslerin dağılımı nasıldır?

\section{Önem}

"Eğitim programlarının iyi tasarlanması ve uygulanması ne kadar önemli ise, programın uygun yöntemlerle değerlendirilip, değerlendirme sonuçlarının programa yansıtılması da bir o kadar önemlidir" (Sapsağlam 2013: 64). Bu doğrultuda, uygulamaya konulan Almanca öğretmenliği lisans programlarının karşılaştırmalı şekilde incelenmesi, geçmişten günümüze Almanca öğretmenliği eğitim programının değişimini ve değişim sonucu alan eğitimi açısından gelinen noktayı göstermesi açısından önemlidir. Program güncelleme gerekçelerinin programlara yansıma biçimlerinin ortaya konulması, yenilenen programların hangi eksiği giderdiğine ilişkin bilgilerin de uygulayıcılara bilgi vermesi açısından önemlidir.

\section{Yöntem}

Çalışmada, nitel araştırma yöntemlerinden olan doküman analizi yöntemi ile içerik çözümlemesi yapılmıştır. "Doküman analizi, yazılı belgelerin içeriğini titizlikle ve sistematik olarak analiz etmek için kullanılan bir nitel araştırma yöntemidir" (Wach, 2013, Akt. Kıral 2020: 173). Bu çalışmada da, Almanca öğretmenliği lisans eğitim programları ile ilgili dokümanlar sistematik bir şekilde analiz edilmiş ve elde edilen bulgular değerlendirilmiştir. İçerik çözümlemesi ise, “(...) belli bir metnin, kitabın, belgenin, belli özelliklerini sayısallaştırarak belirleme amacı ile yapılan bir taramadır" (Karasar 2009: 184). Bu çalışmada Almanca öğretmenliği lisans programlarında alan ve alan öğretimi bilgisi ile ilgili derslerin yıllara göre değişimlerini incelemek amacıyla, ders dağılımları ele alınmış ve tablolar halinde sunulmuştur. Bu kapsamda, 1998 1999, 2006-2007 ve 2018-2019 Almanca öğretmenliği lisans programlarında dersler incelenmiş, ders içeriklerine göre kategorilere ayrılmıştır. Kategorilerin oluşturulmasında Genç ve Çetintaş'ın (1999: 222) alan derslerini sınıflama biçimi esas alınmıştır. Bu sınıflama esasında alan dersleri öğretim içerikleri göz önünde 
bulundurularak, temel dil becerileri, dilbilgisi, dilbilimi, edebiyat bilimi, ülke bilgisi, kültür bilim ve yabancı dil öğretimi ölçüt alınarak kategorize edilmiştir. Alan ve alan öğretimi dersleri ders saatleri, zorunlu ve seçmeli olma durumu ile program içerisinde genel dağılım olarak gösterilmekte ve tablolar halinde sunulmaktadır.

\section{Bulgular}

\section{8-1999 Almanca Öğretmenliği Lisans Programı Geliştirme Gerekçeleri}

Öğretmen yetiştirmede yeni gelişmeler ve yönelimlerin ortaya çıkardığ uygulamada olan programlarda süregelen sorunlar, 1997-1998 y1lında uygulamaya konulan sekiz yıllık zorunlu ilköğretim eğitimi lisans eğitim programlarının yeniden düzenlenmesini zorunlu kılmıştır. Yeni program ile Milli Eğitime öğretmen yetiştiren kurumların gerçekçi ve ihtiyaca dönük bir şekilde eğitim ve öğretim faaliyetlerini yürütebilmesi amaçlanmıştır (YÖK 1998). Bu amaçla, öğretmen yetiştirme programları incelenmiş ve eksiklikleri tespit edilmiştir. Programlarda içerik, ders sayıları ve kredi sayısı gibi konularda bir standardın olmadığı, programlarda yer alan “(...) dersler arasında aşamalı ve birbirlerini tamamlayıcı mantıksal bir ilişkinin kurulamadığı, teorik derslere ağırlık verildiği ve uygulamanın büyük ölçüde ihmal edildiği” (YÖK 1998: 4) saptanmıştır. Bununla birlikte, alan öğretimine yönelik derslerin yetersizliği, programlarda açılan derslerin ilgili okul düzeyinin ihtiyaçları doğrultusunda şekillenmediği ve programın bütünü ile okullarda yapılan uygulama arasında tutarsızlıklar tespit edilmiştir (YÖK 1998: 4). Dolayısıyla “(...) uygulanan programlardan mezun olan öğretmen adaylarının öğretmenlik mesleğine yeterli bir biçimde hazırlanamadıkları saptanmıştır" (YÖK 1998: 4). Tespit edilen bu eksikliklerin giderilmesi amacıyla, 1998-1999 eğitim ve öğretim yılından itibaren uygulamaya konulan Eğitim Fakülteleri lisans programı oluşturulmuştur.

Yükseköğretim Kurumu tarafından ifade edilen bu gerekçeler, tüm Eğitim Fakültelerinin lisans programları için geçerli olduğundan, Almanca öğretmenliği lisans programı da bu kapsamda ele alınmıştır. Yenilenen Almanca öğretmenliği lisans programı üzerine Polat ve Tapan'1n (2002: 53) yaptıkları değerlendirmeler incelendiğinde ise, programın Almanca öğretmeni eğitiminde yeni bir dönemin başlangıc1 olduğunun vurgulandığı ve Almanca öğretmeni eğitiminin temelde bir değişime uğramış olduğu ifade edilmektedir. Temel değişiklikler arasında, Almanca öğretmenlerinin sadece Eğitim Fakültelerinde eğitilmelerinin zorunlu olması ve yeni program ile o güne kadar filoloji ve alan bilgisi ağırlıklı olan eğitimin, meslek ve uygulama odaklı bir eğitime dönüşmüş olması sayılmaktadır (Polat/ Tapan 2002: 5354). Dolayısıyla, 1998-1999 Almanca öğretmenliği lisans programı ile mesleğe yönelik derslerin ağırlık kazanmış olduğu çıkarımında bulunulabilir. Sakarya Maden (2000) 1998 - 1999 Almanca öğretmenliği lisans programını mevcut program ile karşılaştırmakta ve 1998-1999 programında dilbilim ve edebiyat ağırlıklı derslerin çıkarıldığını göstermektedir. Erişkon Cangil (2000) ise, 1998-1999 Almanca öğretmenliği lisans programında toplamda haftalık ders saati olarak dil becerilerine $\% 23$, yöntem ve didaktik için $\% 30$, öğretmenlik uygulamasına $\% 8$, dil bilime $\% 6$, edebiyat bilime $\% 13$ ve çeviriye $\% 4$ oranında yer verildiğini ifade etmektedir. Seçmeli 
derslere \%9, zorunlu dersler olan Türkçe ve Atatürk İlkeleri ve İnkılap Tarihi derslerine ise \%7 oranında yer verilmektedir (Erişkon Cangil 2000: 66).

Dolayısıyla, 1998-1999 Almanca öğretmenliği lisans programı, Almanca öğretmeni yetiştirilmesinde mesleki bilgi açısından temel değişikliklere yol açmıştır. Ancak, Seyhan Yücel 2000 yılında Prof. Dr. Nilüfer Tapan danışmanlığında yürütmüş olduğu "Türkiye Üniversitelerinde Alman Dili Eğitimi Anabilim Dalında Son Gelişmeler Işığında Yeniden Yapılanma ve Program Geliştirme. Nereden? Nereye?” (Seyhan Yücel 2000) adlı Doktora tezinde, uygulanan programın henüz çok kısa bir geçmişinin olduğunu ve kesin sonuçlara varmak için henüz erken olduğunu ifade etmektedir. Nitekim, programın uygulanması ile birlikte geçen zaman içerisinde, programın eksiklikleri fark edilmiş ve 2006-2007 yılında yeni program uygulamaya konulmuştur.

\section{6-2007 Almanca Öğretmenliği Lisans Programı Geliştirme Gerekçeleri}

Daha önceden ifade edildiği gibi, 2006-2007 yılında uygulamaya konulan Almanca öğretmenliği lisans programı, 1998-1999 yılı lisans programının eksikliklerini gidermek amacıyla geliştirilmiştir. $\mathrm{Bu}$ eksiklikler arasında programın, öğretmen adaylarını öğretmen yeterlilikleri konusunda çağın gerektirdiği bilgi ve beceriler ile yeterince donatmadığı bulunmaktadır. Ayrıca 2003-2004 yılından itibaren ilköğretim programlarında yapılan değişiklikler de lisans programlarının yeni duruma uygun hale getirilmesini gerektirmiştir. Bununla birlikte 2003 yılından itibaren ülkemizin de içinde bulunduğu ve Bologna Süreci kapsamında Avrupa Yükseköğretim Alanı oluşturma çalışmaları da gerekçe olarak gösterilmektedir (YÖK 2007: 7). Bologna Süreci kapsamında, Avrupa yükseköğretim kurumlarına belli standartların getirilmesi ve uygulamada birliğin sağlanması amaçlanmaktadır. Bu şekilde, yükseköğretim kurumları arasında geçişlerin kolaylaşması, hareketliliğin sağlanması ve yakın işbirliğinin artırılması hedeflenmektedir. Bu kapsamda eğitim programlarında, süreç, ders, ders içerikleri ve öğrenme çıktılarına yer verilmektedir (Bologna Declaration 1999). Avrupa yükseköğretim alanına uyum çalışmaları kapsamında ülkemizde de uygulamada olan lisans programlarının gözden geçirilmesi ve güncellenmesi zorunluluğu doğmuştur.

2006-2007 programlarıyla getirilen yenilikler arasında, alan bilgisi ve beceriler derslerinin \%50, öğretmenlik meslek bilgisi ve becerileri derslerinin $\% 30$ ve genel kültür derslerinin ise \%20 oranında programlarda temsil edilmesidir. Ancak eğitim programlarına göre bu oranlar ve ders saatleri farklılıklar göstermektedir. Ayrıca çakılı ders programı uygulaması esnetilerek, fakültelere, bir programdaki toplam kredinin yaklaşık \%25'ine varan oranlarda, dersleri belirleme yetkisi verilmiş ve seçmeli ders sayıs1 arttırılmıştır (YÖK 2007: 8). Öte yandan 2006-2007 programında genel kültür derslerinin önemine vurgu yapılmakta ve bu derslerin artırılma gerekçeleri açıklanmaktadır.

$\mathrm{Bu}$ değişikliğin amacı üniversite düzeyinde yetiştirilen öğretmen adayına aydın bir kişide bulunması gereken entelektüel donanımı kazandırmaktır. Belli düzeyde genel kültüre ve bilişim teknolojisine ilişkin bilgi ve becerilere sahip olan, bilimsel araştırma yapabilen ve yapılan araştırmalardan yaralanabilen, çok yönlü bir öğretmen adayı, çağdaş eğitimin gereklerini yerine getirmede daha başarılı olacaktır (YÖK 2007: 8). 
Ancak Uslu'nun (2006) değerlendirmesine göre, tıpk1 1998-1999 programında olduğu gibi 2006-2007 programı da Almanca öğretmenliğinin temel sorunlarını göz önünde bulundurmamaktadır.

Çünkü bu bölümlere İngilizce puanıla gelen öğrencilerin dil sorunu varken, öğrencilerin dil bilgi ve becerilerini yükseltmeye yönelik derslerin artırılmadığı görülmektedir. Bunun yerine yalnızca bazı derslerin adları ve yerlerinin değiştirildiği, genel kültür derslerinin artırılmasıyla öğrencilerin kamu personeli sınavına hazırlanmasına yönelik düzenlemelerin yapılmış olduğu söylenebilir (Uslu 2006: 184).

Ancak yine de yapılan değişiklikler olumlu bulunmaktadır (Uslu 2008: 410). 1998-1999 programında olduğu gibi 2006-2007 programı da zamansal beklentilere karşılık verememiş ve 2018-2019 yılında günümüzde uygulanan yeni lisans programı oluşturulmuştur.

\section{8-2019 Almanca Öğretmenliği Lisans Programı Geliştirme Gerekçeleri}

Öğretmen yetiştirme lisans programlarının güncellenmesi üzerinden geçen on yıllık sürede, kullanılan programların ihtiyaç ve taleplere ne ölçüde karşılık verdiği üzerine değerlendirmeler yapılmıştır. Bu değerlendirmeler sonucunda, alan öğretimi ve meslek bilgisine yönelik derslerin yeniden oluşturulmasına ve programlarda bunlara ağırlık verilmesine karar verilmiştir. Ayrıca, programların Milli Eğitim Bakanlığının yeniden hazırladığı ders programları ile uyumlu hale getirilmesi kararlaştırılmıştır (YÖK 2018: 11). Bununla birlikte 2018-2019 y1lında uygulamaya giren programın güncelleme gerekçeleri arasında, Milli Eğitim Bakanlığının öğretmenlik alanında yaptığı düzenlemeler ile Öğretmenlik Mesleği Genel Yeterliliklerinin (MEB 2017) yeniden hazırlanması ve Öğretmen Stratejisi Belgesinin yayınlaması bulunmaktadır. Ayrıca Avrupa yükseköğretim alanında Bologna sürecine uyum, kalite ve akreditasyon çalışmaları programın gözden geçirilmesini gerekli kılmıştır (YÖK 2018: 12). Bologna süreci kapsamında müfredatta en az \%25 oranında seçmeli derslere yer verilmesi gerektiği ifade edilmekte, ancak öğretmen yetiştirme programlarında fakültelerde yüzlerce farklı ad altında seçmeli derslerin açıldığı, seçmeli derslere ilişkin havuzun gerekli olduğu ifade edilmektedir (YÖK 2018).

\section{Almanca Öğretmenliği Lisans Programlarının Geliştirilme Gerekçelerine İlişsin Genel Değerlendirme}

Öğretmen eğitimi lisans programlarının oluşturulma gerekçeleri incelendiğinde, her üç programın amaçları arasında öğretmen eğitimi lisans programlarına bir standart getirme olduğu görülmektedir. Özellikle 2006-2007 ve 2018-2019 eğitim programlarının Bologna Süreci kapsamında oluşturulmaya çalışılan Avrupa yükseköğretim alanına uyum sağlamak amacıyla geliştirildiği de anlaşılmaktadır. Almanca öğretmenliği lisans programlarının geliştirilme gerekçeleri incelendiğinde, her üç programda da vurgunun Milli Eğitime öğretmen yetiştiren kurumların, öğretmen adaylarını mesleğe yeterince hazırlayamadığı konusuna yapıldığı görülmektedir. Alan öğretimi derslerinin yetersizliği, programlarda yer alan derslerin okullarda yapılan uygulama ile tutarsız olması (YÖK 1998: 4), öğretmen adaylarının yeterlilikler konusunda çağın gerektirdiği bilgi ve beceriler ile donatılamaması (YÖK 2007: 7) ve Öğretmenlik Mesleği Genel Yeterliliklerinin (MEB 2017) yeniden hazırlanması ve programlarında da bu çerçeveyle 
uyumlu olarak yeniden oluşturulması zorunluluğu (YÖK 2018: 12) başlıca gerekçeler arasında gösterilmektedir. Bu gerekçeler, her üç programda da öğretmen adaylarının yeterliliklerinin istenilen düzeyde olmadığına işaret etmektedir.

\section{8-1999 Almanca Öğretmenliği Lisans Programında Derslerin Dağılımı}

Tablo 1'de 1998 - 1999 Almanca öğretmenliği lisans programında bulunan derslerin temel dil becerileri, dilbilgisi, çeviri bilim, dilbilim, edebiyat bilimi, ülke bilgisi, kültür bilim ve yabancı dil öğretimi başlıkları altında dağılımları yer almaktadır. Ayrıca teorik (T) ve uygulama (U) ders saatleri ile birlikte elde edilen kredi (K) sayısı da verilmektedir.

\begin{tabular}{|c|c|c|c|c|}
\hline & & $\mathbf{T}$ & $\mathbf{U}$ & $\mathbf{K}$ \\
\hline \multirow[t]{8}{*}{ Temel Dil Becerileri } & Konuşma Becerileri I & 3 & 0 & 3 \\
\hline & Konuşma Becerileri II & 3 & 0 & 3 \\
\hline & Okuma Becerileri I & 3 & 0 & 3 \\
\hline & Okuma Becerileri II & 3 & 0 & 3 \\
\hline & Yazma Becerileri I & 3 & 0 & 3 \\
\hline & Yazma Becerileri II & 3 & 0 & 3 \\
\hline & İleri Okuma Becerileri & 3 & 0 & 3 \\
\hline & İleri Yazma Becerileri & 3 & 0 & 3 \\
\hline \multirow[t]{2}{*}{ Dilbilgisi } & Almanca Dilbilgisi I & 3 & 0 & 3 \\
\hline & Almanca Dilbilgisi II & 3 & 0 & 3 \\
\hline \multirow[t]{2}{*}{ Çeviri Bilim } & Almanca - Türkçe Çeviri & 3 & 0 & 3 \\
\hline & Türkçe - Almanca Çeviri & 3 & 0 & 3 \\
\hline \multirow[t]{2}{*}{ Dilbilimi } & Dilbilime Giriş I & 3 & 0 & 3 \\
\hline & Dilbilime Giriş II & 3 & 0 & 3 \\
\hline \multirow[t]{6}{*}{ Edebiyat Bilimi } & Alman Edebiyatına Girişi I & 3 & 0 & 3 \\
\hline & Alman Edebiyatına Giriş II & 3 & 0 & 3 \\
\hline & Roman İncelemesi ve Öğretimi & 3 & 0 & 3 \\
\hline & Kısa Öykü İncelemesi ve Öğretimi & 3 & 0 & 3 \\
\hline & Drama (Oyun) İnceleme ve Öğretimi & 3 & 0 & 3 \\
\hline & Şiir İncelemesi ve Öğretimi & 3 & 0 & 3 \\
\hline Ülke Bilgisi & & - & - & - \\
\hline Kültür Bilim & & - & - & - \\
\hline \multirow[t]{6}{*}{ Yabancı Dil Öğretimi } & Dil Edinimi & 3 & 0 & 3 \\
\hline & Almanca Öğretiminde Yaklaşımlar & 3 & 0 & 3 \\
\hline & Çocuklara Yabancı Dil Öğretimi & 3 & 0 & 3 \\
\hline & Almanca Sınav Hazırlama ve Değerlendirme & 3 & 0 & 3 \\
\hline & Materyal Değerlendirme ve Uyarlama & 3 & 0 & 3 \\
\hline & Konu Alanı Ders Kitabı İncelemesi & 2 & 2 & 3 \\
\hline
\end{tabular}

Tablo 1: 1998 -1999 Almanca Öğretmenliği Lisans Programında Alan Eğitimi Derslerinin Dağılımı

1998-1999 Almanca öğretmenliği lisans programında alan eğitimi dersleri incelendiğinde (Tablo 1), toplam 26 dersin yer aldığ1 görülmektedir. Toplam ders sayıs1 açısından temel dil becerilerinde 8 , dilbilgisi ile ilgili 2, çeviri bilimde 2, dilbilimde 2, edebiyat bilimde 6 ve yabancı dil öğretimine ait 6 ders bulunmaktadır. Ülke bilgisi ve kültür bilim başlıkları altında ders yer almamaktadır. Ders saati açısından incelendiğinde, temel dil becerileri derslerine toplamda 24 saat, dilbilgisi, çeviri bilim ve dilbilim altında yer alan derslere 6'şer saat yer verildiği görülmektedir. Edebiyat bilim altında yer alan derslere toplamda 18 saat, yabancı dil öğretimi altında yer alan 
derslere ise toplamda 17 saat yer verilmektedir. Ayrıca yabancı dil ögrretimi altında yer alan Konu Alanı Ders Kitabı İncelemesi dersinde 2 saat uygulama dersi bulunmaktadır.

\section{6-2007 Almanca Öğretmenliği Lisans Programında Derslerin Dağılımı}

Tablo 2 ise 2006-2007 Almanca öğretmenliği lisans programında alan eğitimi derslerinin kategorilere göre dağılımını göstermektedir.

\begin{tabular}{|c|c|c|c|c|}
\hline \multicolumn{2}{|r|}{ Zorunlu } & $\mathbf{T}$ & $\mathbf{U}$ & $\mathbf{K}$ \\
\hline \multirow[t]{8}{*}{ Temel Dil Becerileri } & Sözlü İletişim Becerileri I & 3 & 0 & 3 \\
\hline & Sözlü İletişim Becerileri II & 3 & 0 & 3 \\
\hline & Okuma Becerileri I & 3 & 0 & 3 \\
\hline & Okuma Becerileri II & 3 & 0 & 3 \\
\hline & Yazma Becerileri I & 3 & 0 & 3 \\
\hline & Yazma Becerileri II & 3 & 0 & 3 \\
\hline & İleri Okuma ve Yazma Becerileri I & 3 & 0 & 3 \\
\hline & İleri Okuma ve Yazma Becerileri II & 3 & 0 & 3 \\
\hline \multirow[t]{4}{*}{ Dilbilgisi } & Almanca Dilbilgisi I & 3 & 0 & 3 \\
\hline & Almanca Dilbilgisi II & 3 & 0 & 3 \\
\hline & Almanca Dilbilgisi III & 3 & 0 & 3 \\
\hline & Karşılaştırmalı Dilbilgisi & 3 & 0 & 3 \\
\hline Çeviri Bilim & & - & - & - \\
\hline \multirow[t]{2}{*}{ Dilbilimi } & Dilbilim I & 3 & 0 & 3 \\
\hline & Dilbilim II & 3 & 0 & 3 \\
\hline \multirow[t]{4}{*}{ Edebiyat Bilimi } & Alman Edebiyatı I & 3 & 0 & 3 \\
\hline & Alman Edebiyatı II & 3 & 0 & 3 \\
\hline & Edebi Metin İnceleme ve Öğretimi I & 3 & 0 & 3 \\
\hline & Edebi Metin İnceleme ve Öğretimi II & 3 & 0 & 3 \\
\hline Ülke Bilgisi & Karşılaştırmalı Ülke Bilgisi & 3 & 0 & 3 \\
\hline Kültür Bilim & & - & - & - \\
\hline \multirow[t]{7}{*}{ Yabancı Dil Öğretimi } & Dil Edinimi & 3 & 0 & 3 \\
\hline & Almanca Öğretiminde Yaklaşımlar I & 3 & 0 & 3 \\
\hline & Almanca Öğretiminde Yaklaşımlar II & 3 & 0 & 3 \\
\hline & Çocuklara Yabancı Dil Öğretimi & 2 & 2 & 3 \\
\hline & Özel Öğretim Yöntemleri II & 2 & 2 & 3 \\
\hline & Materyal Geliştirme ve Uyarlama & 2 & 2 & 3 \\
\hline & Almanca Ders Kitabı İncelemesi & 2 & 2 & 3 \\
\hline \multirow[t]{4}{*}{ Seçmeli Dersler } & Seçmeli I & 2 & 0 & 2 \\
\hline & Seçmeli II & 2 & 0 & 2 \\
\hline & Seçmeli III & 2 & 0 & 2 \\
\hline & Seçmeli IV & 2 & 0 & 2 \\
\hline
\end{tabular}

Tablo 2: 2006-2007 Almanca Öğretmenliği Lisans Programında Alan Eğitimi Derslerinin Dağılımı

2006-2007 Almanca öğretmenliği lisans programında alan eğitimi dersleri incelendiğinde (Tablo 2), toplam 26 zorunlu ve 4 seçmeli dersin yer aldiğ görülmektedir. Toplam ders sayısı açısından bakıldığında temel dil becerilerinde 8, dilbilgisinde 4 , dilbilimde 2 , edebiyat bilimde 4 ve yabancı dil öğretiminde 7 ders bulunmaktadır. Ülke bilgisinde 1 ders yer almaktadır. Çeviri bilim ve kültür bilim başlıkları altında ders yer almamaktadır. Ders saati açısından incelendiğinde, temel dil becerileri derslerine toplamda 24 saat, dilbilgisi 12 , dilbilim 6 , edebiyat bilim 12, ülke bilgisi 3, yabanc1 dil öğretimi altında ele alınan derslere 17 saat teorik, 8 saat ise uygulama dersi öngörülmektedir. Seçmeli derslerin ise toplam süresi 8 saat olmaktadır. 


\section{8-2019 Yılı Almanca Öğretmenliği Lisans Programında Derslerin Dağılımı}

Tablo 3 ise, 2018-2019 y1lı Almanca Öğretmenliği Lisans Programında alan eğitimi derslerinin dağılımını göstermektedir.

\begin{tabular}{|c|c|c|c|c|c|c|c|c|}
\hline & Zorunlu & $\mathbf{T}$ & $\mathbf{U}$ & $\mathbf{K}$ & Seçmeli (6) & $\mathbf{T}$ & $\mathbf{U}$ & $\overline{\mathbf{K}}$ \\
\hline Temel Dil & Okuma Becerileri 1 & 2 & 0 & 2 & & & & \\
\hline \multirow[t]{6}{*}{ Becerileri } & Okuma Becerileri 2 & 2 & 0 & 2 & & & & \\
\hline & Yazma Becerileri 1 & 2 & 0 & 2 & & & & \\
\hline & Yazma Becerileri 2 & 2 & 0 & 2 & & & & \\
\hline & Sözlü İletişim Becerileri 1 & 2 & 0 & 2 & & & & \\
\hline & Sözlü İletişim Becerileri 2 & 2 & 0 & 2 & & & & \\
\hline & İleri Okuma ve Yazma Becerileri & 2 & 0 & 2 & & & & \\
\hline \multirow[t]{3}{*}{ Dilbilgisi } & Almancanın Yapıs1 I & 2 & 0 & 2 & İleri Almanca Dilbilgisi & 2 & 0 & 2 \\
\hline & Almancanın Yapısı II & 2 & 0 & 2 & Karşılaştırmalı Almanca & 2 & 0 & 2 \\
\hline & Almancanın Yapıs1 III & 2 & 0 & 2 & Dilbilgisi & & & \\
\hline \multirow[t]{2}{*}{ Çeviri Bilim } & & - & - & - & Türkçe - Almanca Çeviri & 2 & 0 & 2 \\
\hline & & & & & Almanca - Türkçe Çeviri & 2 & 0 & 2 \\
\hline \multirow[t]{2}{*}{ Dilbilimi } & Dilbilim I & 2 & 0 & 2 & Sosyodilbilimi ve Dil Öğretimi & 2 & 0 & 2 \\
\hline & Dilbilim II & 2 & 0 & 2 & Dil Felsefesi & 2 & 0 & 2 \\
\hline Edebiyat & Alman Edebiyatı I & 2 & 0 & 2 & & & & \\
\hline \multirow[t]{3}{*}{ Bilimi } & Alman Edebiyatı II & 2 & 0 & 2 & & & & \\
\hline & Almanca Öğretiminde Edebi & 3 & 0 & 3 & & & & \\
\hline & $\begin{array}{l}\text { Almanca Öğretiminde Edebi } \\
\text { Metinler } 2\end{array}$ & 3 & 0 & 3 & & & & \\
\hline Ülke Bilgisi & & - & - & - & Karşılaştırmalı Ülke Bilgisi & 2 & 0 & 2 \\
\hline Kültür Bilim & & - & - & - & $\begin{array}{l}\text { Kültürlerarası Öğrenme ve } \\
\text { Öğretme }\end{array}$ & 2 & 0 & 2 \\
\hline Yabancı Dil & Almanca Öğrenme ve Öğretim & 2 & 0 & 2 & Almanca Öğretiminde Drama & 2 & 0 & 2 \\
\hline \multirow[t]{11}{*}{ Öğretimi } & Yaklaşımları & & & & Almanca Öğretiminde Materyal & 2 & 0 & 2 \\
\hline & Almanca Öğretim Programları & 2 & 0 & 2 & Tasarımı & & & 2 \\
\hline & $\begin{array}{l}\text { Almanca Dil Becerilerinin } \\
\text { Öğretimi } 1\end{array}$ & 3 & 0 & 3 & $\begin{array}{l}\text { Almanca Öğretiminde Yeni } \\
\text { Teknolojiler }\end{array}$ & 2 & 0 & 2 \\
\hline & & 3 & 0 & 3 & Sınıf İçi Öğrenmelerin & 2 & 0 & \\
\hline & $\begin{array}{l}\text { Almanca Dil Becerilerinin } \\
\text { Öğretimi } 2\end{array}$ & 3 & 0 & 3 & Değerlendirilmesi & & & \\
\hline & Dil Edinimi & 2 & 0 & 2 & & & & \\
\hline & Almanca Ders Kitab1 İncelemesi & & & & & & & \\
\hline & $\begin{array}{l}\text { Çocuklara Yabancı Dil Öğretimi } \\
\text { Almanca Öğretiminde Ders İçeriği }\end{array}$ & 3 & 0 & 3 & & & & \\
\hline & Geliştirme & 2 & 0 & 3 & & & & \\
\hline & Almanca Öğretiminde Sınav & & & & & & & \\
\hline & Hazırlama & 2 & 0 & 3 & & & & \\
\hline
\end{tabular}

Tablo 3: 2018-2019 Almanca Öğretmenliği Lisans Programında Alan Eğitimi Derslerinin Dağılımı

2018-2019 Almanca öğretmenliği lisans programında alan eğitimi dersleri incelendiğinde (Tablo 3), toplam 25 zorunlu ve 12 seçmeli dersin yer aldı̆̆ görülmektedir. Toplam ders sayısı açısından bakıldığında zorunlu dersler olarak temel dil becerilerinde 7 , dilbilgisinde 3 , dilbilimde 2 , edebiyat bilimde 4 ve yabanc1 dil öğretiminde 9 ders bulunmaktadır. Ülke bilgisi, çeviri bilim ve kültür bilim alanlarında ders bulunmamaktadır. Ders saati açısından incelendiğinde, temel dil becerileri derslerine toplamda 14 saat, dilbilgisi 6, dilbilim 4, edebiyat bilim 10, yabanc1 dil öğretimi altında ele alınan derslere 22 saat teorik ders öngörülmektedir. Seçmeli dersler incelendiğinde ise, alınması gereken 6 seçmeli dersin zorunlu olduğu, 12 dersin ise 
programda seçime sunulduğu görülmektedir. Dilbilgisi, çeviri bilim ve dilbilim alanlarında 2'şer seçmeli ders bulunmaktadır. Ülke bilgisi ve kültür bilim alanlarında 1 'er ders bulunmaktadır. Yabancı dil öğretimi başlığı altında ise 4 dersin yer aldığ görülmektedir. Her seçmeli derse 2 saat ders öngörülmektedir.

\section{Almanca Öğretmenliği Lisans Programları Ders Dağılımlarının Karşılaştırılmasına İliş̧kin Bulgular}

Tablo 4 ise, 1998-1999, 2006-2007 ve 2018-2019 Almanca öğretmenliği lisans programlarında alan eğitimi, genel kültür ve meslek bilgisi derslerinin teorik, uygulama ve kredi dağılımları yer almaktadır.

\begin{tabular}{|c|c|c|c|c|c|c|c|c|c|c|c|c|}
\hline & \multicolumn{4}{|c|}{ 1998-1999 } & \multicolumn{4}{|c|}{ 2006-2007 } & \multicolumn{4}{|c|}{ 2018-2019 } \\
\hline & $\mathrm{T}$ & $\mathrm{U}$ & $\mathrm{K}$ & $\mathrm{S}$ & $\mathrm{T}$ & $\mathrm{U}$ & $\mathrm{K}$ & $\mathrm{S}$ & $\mathrm{T}$ & $\mathrm{U}$ & $\mathrm{K}$ & $\mathrm{S}$ \\
\hline Temel Dil Becerileri & 24 & 0 & 24 & 24 & 24 & 0 & 24 & 24 & 14 & 0 & 14 & 14 \\
\hline Dilbilgisi & 6 & 0 & 6 & 6 & 12 & 0 & 12 & 12 & 6 & 0 & 6 & 6 \\
\hline Çeviri Bilim & 6 & 0 & 6 & 6 & 0 & 0 & 0 & 0 & 0 & 0 & 0 & 0 \\
\hline Dilbilim & 6 & 0 & 6 & 6 & 6 & 0 & 6 & 6 & 4 & 0 & 4 & 4 \\
\hline Edebiyat Bilimi & 18 & 0 & 18 & 18 & 12 & 0 & 12 & 12 & 10 & 0 & 10 & 10 \\
\hline Ülke Bilgisi & 0 & 0 & 0 & 0 & 3 & 0 & 3 & 3 & 0 & 0 & 0 & 0 \\
\hline Kültür Bilim & 0 & 0 & 0 & 0 & 0 & 0 & 0 & 0 & 0 & 0 & 0 & 0 \\
\hline Yabancı Dil Öğretimi & 18 & 2 & 18 & 20 & 17 & 8 & 21 & 25 & 22 & 0 & 24 & 22 \\
\hline Alan Dersleri Toplamı & 77 & 2 & 78 & 87 & 74 & 8 & 78 & 82 & 56 & $\mathbf{0}$ & 58 & 56 \\
\hline Seçmeli Alan Dersi Toplamı & 13 & 0 & 13 & 13 & 8 & 0 & 8 & 8 & 12 & 0 & 12 & 12 \\
\hline Meslek Bilgisi & 24 & 24 & 36 & 48 & 28 & 14 & 35 & 42 & 44 & 12 & 50 & 56 \\
\hline Genel Kültür & 17 & 0 & 13 & 17 & 26 & 6 & 29 & 32 & 26 & 2 & 27 & 28 \\
\hline Genel Toplam & 133 & 28 & 147 & 161 & 142 & 28 & 156 & 170 & 138 & 14 & 145 & 152 \\
\hline
\end{tabular}

Tablo 4: Almanca Öğretmenliği Lisans Programlarında Derslerin Teorik, Uygulama, Kredi ve Ders Saati Açısından Dağılımı

Tablo 4 incelendiğinde, 1998-1999 Almanca öğretmenliği lisans programinda 133 saat teorik ve 28 saat uygulama olmak üzere 161 saat ders bulunmaktadır. Alan eğitimi dersleri için 77 saat teorik, 2 saat uygulama olmak üzere toplamda 79 saat ders öngörülmektedir. Elde edilen kredi sayısı ise 78'dir. Programda meslek bilgisi derslerine teorik 24 ve uygulama 24 saat olmak üzere toplamda 48 saat yer ayrılmaktadır. Elde edilen kredi sayısı ise 36'dır. 2006-2007 Almanca öğretmenliği lisans programı incelendiğinde, alan eğitimi derslerinin toplam teorik ders saati 74 , uygulama dersleri ise 8 saattir. Bu şekilde alan eğitimi dersleri toplamda haftalık 82 saat olarak görülmektedir. Seçmeli alan eğitimi dersleri ise teorik olarak 8 saat olarak yer almaktadır. Meslek bilgisi dersleri genel toplamda teorik 28 saat, uygulama 14 saat olmak üzere 42 saat görülmektedir. Elde edilen kredi sayısı ise $35^{\prime}$ dir. Genel kültür derslerine genel toplamda 32 saat olmak üzere teorik olarak 26 saat, uygulama olarak 6 saat yer verilmektedir. Elde edilen kredi sayıs1 ise 29'dur. 2018-2019 Almanca öğretmenliği lisans programında alan eğitimi dersleri toplamda 56 saat teorik ders olarak yer almaktadır. Elde edilen kredi sayısı ise 58'dir. Seçmeli alan eğitimi dersleri ise 12 saat teorik ders olarak görülmektedir. Meslek bilgisi dersleri ise teorik olarak 44 saat, uygulama olarak 12 saat olmak üzere toplamda 56 saat olarak verilmektedir. Elde edilen kredi sayısı ise 50'dir. Genel kültür dersleri ise teorik 26 saat, uygulama 2 saat olmak üzere toplam 28 saat yer almaktadır. Elde edilen kredi sayısı ise 27'dir. 
Derslerin yıllara göre dağılımı incelendiğinde, alan eğitimi derslerinde ders saatinde azalmanın olduğu görülmektedir. Bu azalma en çok temel dil becerilerinde olmaktadır. Temel dil becerileri derslerine 1998-1999 ve 2006-2007 programlarında toplamda 24 saat yer verilirken, 2018-2019 programında 14 saat yer verilmektedir. 2018-2019 programında temel dil becerileri altında seçmeli ders sunulmamaktadır. Dilbilgisi başlığı altında incelendiğinde ise, 1998-1999 ve 2018-2019 programlarında derslerin 6'şer saat olarak yer aldığ 1 , ancak 2018-2019 programında iki tane dilbilgisi dersinin seçmeli olarak sunulduğu görülmektedir. Bununla birlikte ders saati 10'a çıkmaktadır. Dilbilgisi konusunda ders saatinin en yüksek olduğu program 2006-2007 programıdır. Çeviri Bilim altında yer alan dersler 1998-1999 yılında 6 saat verilmektedir, 2006-2007'de ise hiç sunulmamaktadır. 2018-2019'de ise, toplamda 4 saat olan iki ders olarak verilmektedir. Dilbilim altında yer alan dersler ise, 1998-1999 ve 2006-2007 programında 6'şer saat verilmektedir. 2018-2019 programında ise 4 saat zorunlu ve 4 saat seçmeli ders olarak sunulmaktadır. Seçmeli derslerin iki tanesinin dilbilim alanından seçilmesi ise birlikte toplam ders saati 8'e çıkacağından, dilbilim alanında 2018-2019 programında bir artış söz konusudur. Edebiyat Bilimde ise, en çok ders saati1998-1999 programında bulunmaktadır. 2006-2007 yılında 18 olan ders saati, 12'ye, 2018-2019 programında ise 10'a düşmektedir. 2018-2019 programında Edebiyat Bilim alanında seçmeli ders verilmemektedir. Ülke Bilgisi konusunda 1998-1999 programında ders bulunmamaktadır, 2006-2007 programında ise 3 saatlik bir zorunlu ders, 2018-2019 programında ise 2 saatlik seçmeli bir ders bulunmaktadır. Kültür Bilim konusunda ise, 1998-1999 ve 2006-2007 programlarında derslere yer verilmezken, 2018-2019 programında 2 saatlik bir seçmeli ders sunulmaktadır. Yabancı dil öğretimi konusunda ise, 1998-1999 programında 20 saat derslere yer verilirken, 2006-2007 programında 25 saat yer verilmektedir. 2018-2019 programında ise zorunlu ders saati 22'ye düşürülmüştür. Ancak toplamda sekiz saate karşılık gelen dört seçmeli ders bulunmaktadır. Alan eğitimi derslerinin programlarda toplam saat dağılımlarına bakıldığında, 1998-1999 programında 87 saat, 2006-2007 programında 82, 2018-2019 programında ise 56 olduğu görülmektedir. Ancak 2018-2019 programında altı tane seçmeli dersin alınması zorunlu olduğundan, toplam saat 68 olmaktadır. Meslek bilgisi dersleri ise 1998-1999 programında 48 saat, 2006-2007 programında 42 saat ve 20182019 programında 56 saat olarak verilmektedir. Genel kültür dersleri 1998-1999 programında 17 saat, 2006-2007'de 32 saat ve 2018-2019 programında 28 saat verilmektedir.

Genel itibariyle, programlarda yer alan derslerin yıllara göre değişimi incelendiğinde, yabancı dil öğretimi, dil bilgisi ve temel dil becerileri altında yer alan derslerin ders saatlerinde azalmanın olduğu, en büyük azalmanın ise temel dil becerileri ile ilgili derslerde olduğu görülmektedir. Dolayısıyla, alan öğretimi ile ilgili derslerin ders saatlerinde genel bir düşüşün olduğu anlaşılmaktadır. Aynı şekilde Edebiyat Bilim ve Dilbilim altında bulunan alan derslerinin ders saatlerinde de bir azalma söz konusudur. Buna karşılık, meslek bilgisi ve genel kültür derslerinin ders saatlerinde bir artışın olduğu da görülmektedir. 


\section{Sonuç}

Nitelikli öğretmenlerin yetiştirilmesi amacıyla eğitim ve öğretim yapan öğretmen eğitimi kurumları, günün beklentilerine cevap verebilmek amacıyla müfredatını gözden geçirmekte ve yenilemektedir. $\mathrm{Bu}$ çalışmada ise, geçmişten günümüze kadar oluşturulmuş olan Almanca öğretmenliği lisans eğitimi programlarının oluşturulma gerekçeleri ve alan derslerinin program içerisindeki dağılımları incelenmektedir.

Çalışmanın birinci araştırma konusu olan "1998-1999, 2006-2007 ve 2018-2019 yıllarında uygulamaya konulan Almanca öğretmenliği lisans programlarının oluşturulma gerekçeleri nelerdir?" sorusunun cevaplanması amaciyla yapılan incelemeden elde edilen bulgular göstermektedir ki, başlıca gerekçe öğretmen adaylarının mesleki yeterliliklerinin, Milli Eğitimin beklentileri ile uyumlu olmamasıdır. Bundan dolayı, yeni oluşturulacak olan Almanca öğretmenliği eğitim programlarında, yabancı dil öğretmenlerinin sahip olması gereken yeterliliklerin göz önünde bulundurulması ve alan öğretimi ile ilgili derslerin ve içeriklerinin belirlenmesinde okullardaki uygulamaların esas alınması önerilmektedir.

Çalışmanın ikinci araştırma konusu ise, "1998-1999, 2006-2007 ve 2018-2019 Almanca öğretmenliği lisans programlarında alan ve alan öğretimi bilgisi ile ilgili derslerin dağılımı nasıldır?" sorusunun cevabının aranmasıdır. Bu kapsamda, çalışmada elde edilen bulgular göstermektedir ki, 2006-2007 yılı lisans eğitim programına göre 2018-2019 yılında yürürlüğe giren Almanca öğretmenliği lisans programında Temel Dil Becerileri, Çeviri Bilim, Dilbilim, Edebiyat Bilim, Ülke Bilgisi, Yabancı Dil Öğretimi ve seçmeli alan dersleri açısından ders saati ve ders sayısı açısından bir azalma söz konusudur. Buna karşılık Meslek Bilgisi ders sayısında ve süresinde bir artışın olduğu anlaşılmaktadır. Yabancı dil öğretmenlerine alan öğretimi bilgisinin verilmesini sağlayacak olan dersler incelendiğinde ise, bu derslerde 1998-1999, 2006-2007 lisans programına göre 2018-2019 yılı programında önemli değişikliklerin olduğu görülmektedir. 1998-1999, 2006-2007 lisans programına göre kıyaslandığında, Dil Edinimi, Çocuklara Yabancı Dil Öğretimi, Ders Kitabı İncelemesi, Sınav Hazırlama ve Değerlendirme ve Almanca Öğretim Yaklaşımları dersleri yerini korumaktadır. Ancak, 2006-2007 yılından itibaren verilen Almanca Öğretiminde Yaklaşımlar I ve II dersleri tek dönem olarak Almanca Öğrenme ve Öğretim Yaklaşımları dersi adı altında verilmektedir. Özel Öğretim Yöntemleri dersi ders programında çıkarılmış, zorunlu olan Materyal Geliştirme ve Uyarlama dersi yerine seçmeli olarak Almanca Öğretiminde Materyal Tasarımı dersi gelmiştir. Bu programda yabancı dil öğretimi başlığı altında ele alınan zorunlu sunulan dört yeni ders yer almaktadır. Bunlar Almanca Öğretim Programları, Almanca Öğretiminde Ders İçeriği Geliştirme, Almanca Dil Becerilerinin Öğretimi I ve II dersleri. Bununla birlikte seçmeli olarak sunulan üç ders de yabancı dil öğretimi konusunda alan öğretiminde yetkinliğin gelişmesini sağlayacak dersler arasında yer almaktadır. Bunlar, Almanca Öğretiminde Yeni Teknolojiler, Sınıf İçi Öğrenmelerin Değerlendirilmesi ve Almanca Öğretiminde Drama dersleridir. Alan öğretimi bilgisi konusunda yetkinlik gelişimine katkı sunacak olan zorunlu dersler incelendiğinde, temel zorunlu dersler arasında yer alması gereken Materyal Geliştirme ve Uyarlama dersinin seçmeli dersler sınıfına alınması ve Özel Öğretim Yöntemleri dersinin programdan tamamen çıkarılması ve günümüz dünyasında dil öğretiminde 
belirleyici olan yeni teknolojilere yönelik bir dersin zorunlu değil de sadece seçmeli ders olarak sunulması programın eksik yönleri olarak göze çarpmaktadır. Sınıf içi öğrenmelerin değerlendirilmesi konusunda ayrı başlık altında bir dersin seçmeli olarak sunulması ise dikkat çekmektedir.

Günün koşullarına uygun bir eğitim programı oluşturma amacıyla geliştirilen 2018 - 2019 yılı Almanca öğretmenliği lisans programında, güncel gereklilikler açısından eksikliklerin olduğu görülmekte ve bu eksikliklerin giderilmesi yönünde çalışmalara ihtiyaç duyulduğu anlaşılmaktadır. Yabancı dil öğretmenlerinin sahip olması gereken ve kendi alanlarındaki yetkinliklerini ortaya koyan temel iki yetkinlik alanın olduğu alan yazında vurgulanmaktadır. Bunlar dilsel yeterlik ve dil öğretme yetkinliğidir (bkz. Königs 2014: 73). Bu iki yetkinlik alanı yabancı dil öğretmenlerini diğer alanlardaki öğretmenlerden ayıran bilgi ve becerileri içermektedir. Tapan (2001) da bu noktaya vurgu yapmakta ve "Nasıl bir Almanca öğretmeni?" sorusuna, "Almanca öğretmen adayları eğitim süreçlerinin sonunda öğretecekleri dilin temel dil becerilerine, dilbilgisine, sözcük bilgisine egemen olmalı, o dili nerede, nasıl doğru olarak kullanacaklarını öğrenmelidirler" (Tapan 2001: 43) ifadesi ile karşılık vermektedir. Ancak bilgi sahibi olmak yeterli bulunmamakta, "Öğretmen adayları eğitim sürecinde yabancı dil bilgilerini öğrencilerine nasıl aktarabileceklerini de öğrenmek zorundadırlar" (Tapan 2001: 43-44) konusuna vurgu yapmaktadır.

$\mathrm{Bu}$ görüşten yola çıkarak yükseköğretim kurumlarının ilgili kurullarının eğitim programlarını hazırlarken, özellikle yabancı dil öğretimi ile ilgili bilgi ve becerileri içeren derslere ağırlık vermesi, bunları seçmeli dersler havuzundan çıkarıp zorunlu olarak sunması ve uygulama derslerine yer vermesi günümüz beklenti ve koşullarına uygun Almanca öğretmenlerinin yetiştirilmesine katkı sunması açısından önemlidir. Program geliştiricilerin bu doğrultuda alacağı kararların, Almanca öğretmeni adaylarının mesleki yeterlilik gelişimlerini destekleyeceği ve Milli Eğitimin beklentilerini karşılayacağı düşünülmektedir.

\section{Kaynakça}

Baumert, Jürgen/ Kunter, Mareike (2006): Stichwort: Professionelle Kompetenz von Lehrkräften. Zeitschrift für Erziehungswissenschaft, 9 (4). 469-520.

Bologna Declaration (1999): The Bologna Declaration of 19 June 1999. https://www.eurashe.eu/library/modernisingphe/Bologna_1999_Bologna Declaration.pdf (Erişim Tarihi: 12.02.2007)

Budak, Yusuf (2009): Mesleki Eğitimde İhtiyaç Analizi ve İşlevsel Eğitim Programı. Gazi Üniversitesi Endüstriyel Sanatlar Eğitim Fakültesi Dergisi, 245. 65 - 75.

Demirel, Özcan (2012): Eğitimde Program Geliştirme. 19. Baskı, Ankara: Pegem Akademi.

Deregözü, Aysel (2020): Yapısal Eşitlik Modellemesi İle Yabancı Dil Öğretme Yetkinliğinin İncelenmesi. (Yayınlanmamış Doktora Tezi). Marmara Üniversitesi Eğitim Bilimleri Enstitüsü, İstanbul.

Erişkon Cangil, Binnur (2000): Deutschlehrerausbildung in der Türkei - Neustrukturierung und Perspektiven. N. Tapan, T. Polat \& H. - W. Schmidt (Hrsg.), Berufbezogene 
Deutschlehrerausbildung. Dokumentation zum Workshop am 26./ 27. Mai 2000. Istanbul: KG Ajans. $63-70$

Genç, Ayten/ Çetintaş, Bengül Gülay (1999): Alman Dili Eğitimi Anabilim Dalı Eski ve Yeni Lisans Programlarının Karşılaştırılması. Buca Eğitim Fakültesi Dergisi, Özel Sayı, 11. 220-229.

Gültekin Mehmet (2013): İlköğretim Öğretmen Adaylarının Eğitim Programı Kavramına Yükledikleri Metaforlar. Eğitim ve Bilim, 38 (169). 126 - 141.

Karasar, Niyazı (2009): Bilimsel Araştırma Yöntemi. 19. Baskı, Ankara: Nobel Yayın Dağıtım.

Kıral, Bilgen (2020): Nitel bir veri analizi yöntemi olarak döküman analizi. Siirt Üniversitesi Sosyal Bilimler Enstitüsü Dergisi, 15. 170-189.

Kocayiğit, Ali/ Aykaç, Necdet (2019): İlkokul Türkçe Öğretim Programının Eğitim Programı Öğeleri Açısından Değerlendirilmesi (1923 - 2017). Mustafa Kemal Üniversitesi Sosyal Bilimler Enstitüsü Dergisi, 16(44). 251-279.

König, Johannes/ Lammerding, Sandra/ Nold, Günter/ Rohde, Andreas/ Strauß, Sarah/ Tachstoglou, Sarantis (2016): Teachers' professional knowledge for teaching English as a foreign language: Assessing the outcomes of teacher education. Journal of Teacher Education, 67(4). $320-337$.

Königs, Frank Gerhard (2009): Zwischen Hoffen und Bangen. Möglichkeiten und Grenzen einer europäischen Studienreform am Beispiel des Faches Deutsch als Fremdsprache. Tagungsdokumentation zum Syposium Perspektiven zur Neustruktierung der Studiengänge Deutsch als Fremdsprache in Südosteuropa. İstanbul. 21-41.

Königs, Frank Gerhard (2014): War die Lernereorientierung ein Irrtum? Der Fremdsprachenlehrer im Kontext der Sprachlehrforschung. FluL, 43(1). $65-80$.

MEB (2017): Öğretmenlik Mesleği Genel Yeterlilikleri. Ankara: Öğretmen Yetiştirme ve Geliştirme Genel Müdürlüğ̈̈.

Polat, Tülin/ Tapan, Nilüfer (2002): Neustrukturierung im Prozess der Deutschlehrerausbildung in der Türkei, Schriftenreihe Deutsch als Fremdsprache II Tagungsdokumentation. Internationales Qualitätsnetz Deutsch als Fremdsprache- Tagungsdokumentation 2002. 28.-30. November 2002, Universität Kassel. $53-64$.

Sakarya Maden, Sevinç (2000): Vergleich des alten und des neuen Curriculums. In N. Tapan, T. Polat \& H. W. Schmidt (Hrsg.), Berufbezogene Deutschlehrerausbildung. Dokumentation zum Workshop am 26./ 27. Mai 2000. Istanbul: KG Ajans. 45-56

Sapsağlam, Özkan (2013): Değerlendirme Boyutuyla Okul Öncesi Eğitim Programları (1952 - 2013). Uluslararası Türk Ĕ̆itim Bilimleri Dergisi, 1(1). 63-73.

Seyhan Yücel, Mukadder (2000): Türkiye Üniversitelerinde Alman Dili Eğitimi Anabilim Dalında Son Gelişmeler Işı̆̆ııda Yeniden Yapılanma ve Program Geliştirme. Nereden? Nereye? (Yayınlanmamış Doktora Tezi), İstanbul Üniversitesi Sosyal Bilimler Enstitüsü, İstanbul.

Tapan, Nilüfer (2001): Eğitimde Yeniden Yapılanma Çerçevesinde Almanca Öğretmenlerinin Yetiştirim Sürecine Eleştirel Bir Bakış, Alman Dili ve Edebiyatı Dergisi, 1. 41-56.

Türk Eğitim Derneği (2009): Öğretmen yeterlikleri. Ankara: Adım Okan Matbaacılık Basım Yayın Tanıtım Organizasyon Ticaret Limited Şirketi.

Uslu, Zeki. (2006): Almanca Öğretmenliği Lisans Programına İlişkin Öğrenci Görüşleri Işı̆̆ında 2006 2007 Öğretim Yılında Yapılan Değişikliklerin Değerlendirilmesi: Dicle Üniversitesi Örneği, Çukurova Üniversitesi Eğitim Fakültesi Dergisi, 2(32). 169 -185.

Uslu, Zeki (2008): Deutschlehrerausbildung in der Türkei. Neustrukturierung und Curriculumrevision. Info DaF, 35(4). 401-411. 
YÖK (1998): Eğitim Fakültesi Öğretmen Yetiştirme Lisans Programları. https://www.yok.gov.tr/Documents/Yayinlar/Yayinlarimiz/egitim-fakultesi-ogretmenyetistirmelisans-programlari-mart-1998.pdf (Son Erişim Tarihi: 17.05.2019).

YÖK (2007): Eğitim Fakültesi Öğretmen Yetiştirme Lisans Programları. https://www.yok.gov.tr/Documents/Yayinlar/Yayinlarimiz/egitim-fakultesi-ogretmenyetistirmelisans-programlari.pdf (Son Erişim Tarihi: 18.05.2019).

YÖK (2018): Yeni Öğretmen Yetiştirme Lisans Programları. https://www.yok.gov.tr/kurumsal/idaribirimler/egitim-ogretim-dairesi/yeni-ogretmen-yetistirmelisans-programlari (Son Erişim Tarihi: 18.05.2019).

YÖK (2020): YÖK’ten Eğitim Fakültelerine Önemli Yetki Devri Kararı. https://www.yok.gov.tr/Sayfalar/Haberler/2020/egitim-fakültelerine-yetki-devri.aspx (Son Erişim Tarihi: 22.05.2019). 